\title{
Multiple Literacies and Success for All: An Analysis of Ontario Educators' Survey Responses
}

\author{
Marie Josée Berger, University of Ottawa \\ deduc@uottawa.ca \\ George J.S. Dei, OISE/University of Toronto \\ gdei@oise.utoronto.ca \\ Renée Forgette-Giroux , University of Ottawa \\ vdprog@uottawa.ca
}

\begin{abstract}
This essay reports on the survey findings of a study examining the teaching and evaluation strategies used by teachers in the classroom. The study focussed on 304 French and English schools in Ontario representing both urban and rural Ontario school boards. The essay begins with a review of the literature and highlights key points noted by educational theorists and practitioners regarding the importance and challenges of literacy education. We then move to discuss our discursive framework with regards to employing cognitive and social constructivism as theoretical lenses. Survey responses are presented under the broader categories of teaching and pedagogical practice and evaluation of teaching strategies. In analyzing the survey results, we highlight the following as being effective in the promotion of critical literacy: a teacher's own knowledge; pedagogical skills and approaches; the level of school and off-school/local knowledge of students; the affirmation of the identity, culture and history of learners, as well as one's knowledge of the local community.
\end{abstract}

\section{Introduction}

It is increasingly being recognized that the cultural responses students learn at home, in terms of cognition, emotion, and behaviour, play a crucial-and often conflicting-role in the way they negotiate the expectations of school literacies. Therefore, it seems important that teachers reflect on why understanding the cultural nature and meaning of the "what" and "how" they teach, with respect to worldviews, can affect the learning outcomes of students. As a result, meeting the province's literacy objectives will require Ontario teachers to listen to and engage with alternative literacies with regard to ethnocultural learners.

This paper is a report of research survey findings of a larger study that sought to further understand the teaching and evaluating strategies used by teachers in the classroom. The larger study investigated the perceptions, views and practices of Ontario teachers related to literacy education. We begin this essay with a review of the literature and by highlighting key points noted by educational theorists and practitioners regarding the importance and challenges of literacy education. We then move to discuss our discursive framework for the broader study and the 
methodological approaches employed, concluding with the survey research data and interpretation of findings.

Canada's ethnocultural profile has become increasingly multi-ethnic and multicultural. The last national census revealed that over two hundred different ethnic groups now inhabit Canada's 13 provinces and territories. Before 1961, 90.4 percent of all immigrants came from European countries. Since then, the sociocultural demographics of immigrants have changed significantly. Between 1991 and 2001, of the 2.2 million immigrants who were admitted to Canada, 58 percent came from Asia, including the Middle East, 20 percent from Europe, 11 percent from the Caribbean, Central and South America, 8 percent from Africa, and 3 percent from the United States. Moreover, one sixth of Canadian residents reported having a mother tongue other than English or French.

For years, Ontario has welcomed the bulk of these newly landed immigrants, and currently about half the province's population is made up of people from minority ethnocultural groups. Ontario's educational institutions are now faced with the challenging task of educating an increasingly diversified student body, of which the majority no longer originates from Europe. Consequently, our attempts as educators to interpret, and then teach the provincial curriculum to ethnocultural students remains an ongoing endeavour. ${ }^{1}$

As public educators, we are expected to understand and validate the differing ways in which various ethnocultural and aboriginal students respond to our classroom environments, curricula, and teaching strategies. Our personal backgrounds-cultural, racial, gender, sexual, class, linguistic, and ethnic identities-play a critical role in the ways we respond to the changing ethnocultural landscape of Ontario classrooms. Students' performance at school "is shaped by the experiences, background knowledge, and social/cultural identities” they bring to any given learning activity (Hassett, 2006, p. 78).

In order to reach the objectives of excellence for all in education in Ontario, the Ministry of Education published several documents: Literacy for Learning (2004), Education for All (2005), Early Reading Strategy (2003), and Teaching and Learning Mathematics (2004). These reports offer teaching and learning strategies that will enable teachers to better meet students' needs in terms of numeracy and literacy in Ontario's Anglophone and Francophone schools. They fully focus on the specific issues that surround students of an ethnocultural minority. However, these issues are significant and require an in-depth examination in light of the factors linked to literacy, such as personal, family-related and academic factors. Several studies have centered on a few of these issues (Lareau \& Hovat, 1999; Jeynes, 2003). KrulgySmolska \& Warren (2001) studied the academic results of adolescents belonging to voluntary, as opposed to involuntary, minority/ethnocultural groups. The findings in

\footnotetext{
${ }^{1}$ The demographic information from this and the previous paragraph is from the following sources: Ghosh and Abdi (2004); and Statistics Canada, (2003, 2002).
} 
the article indicate that the majority of the students who belong to voluntary, as opposed to involuntary, minority and ethnocultural groups excel academically despite language barriers and racial discrimination.

Existing research (see Solomon \& Sekayi, 2007; Ladson-Billings \& Tate, 2006; Dei, et. al 2000; King, 1997) indicates that it is critical for teachers to be culturally responsive. Students' responses to the school curriculum will vary depending on how they are situated within their own ethnocultural communities, and how those communities are situated with respect to the dominant sociocultural practices reproduced by teachers within the school. In turn, students' potential successes and failures with the learning outcomes expected at school are influenced by the particular individual personalities of students and by the values of the cultures in which they have been raised at home. Current research shows (see Solomon \& Sekayi, 2007; Ladson-Billings \& Tate, 2006; Dei, et. al 2000; King, 1997) that it is important for teachers to acknowledge the differences between the social practices at home and those expected at school.

According to research, the following characteristics define a culturally responsive teacher:

a. The teacher is socioculturally conscious, that is, recognizes that there are multiple ways of perceiving reality and that these ways are influenced by one's location in the social order.

b. The teacher affirms the views of students from diverse backgrounds, seeing resources for learning in all students rather than viewing differences as problems to be overcome.

c. The teacher sees himself or herself as both responsible for and capable of bringing about educational change that will make schools more responsive to all students.

d. The teacher understands how learners construct knowledge and is capable of promoting learners' knowledge construction.

e. The teacher knows about the lives of his or her students.

f. The teacher uses knowledge about students' lives to design instruction that builds on what they already know while stretching them beyond the familiar.

g. The teacher knows which ethnic groups give priority to communal living and cooperative problem solving and how these preferences affect educational motivation, aspiration, and task performance.

h. The teacher (a) acknowledges how different ethnic groups' protocols for regulating the ways children interact with adults are exhibited in instructional settings and (b) understands the implications of gender role socialization in different ethnic groups for implementing equity initiatives in classroom instructions (Villegas \& Lucas, 2002, p. 21; Gay, 2000, p. 107).

Schools must offer a learning environment that supports students' personal experiences while taking into consideration their cultural backgrounds. This environment will also afford students the opportunity to implicate themselves in significant activities that have a link to a world outside of the classroom (National Research Council \& Institute of Medicine, 2004). Students must be given the chance to participate in school activities and after-school programs that will allow them to develop a variety of skills and competencies. As a result, schools are no longer 
considered establishments removed from reality, but a possible learning environment useful for projects (Acker, Inzirillo, \& Lefebvre, 2000).

\section{Discursive Framework}

Literacy and culture go hand in hand. Students who see themselves reflected and affirmed in classroom texts and in instruction come to appreciate that reading and writing are genuinely for them and about them (p. 5, Literacy for Learning - The Report of the Expert Panel on Literacy in Grades 4 to 6 in Ontario). There exist four fundamental principles that act as a guide for individual and collective activity:

1. Individual and collective activities are necessary in the construction of knowledge.

2. Knowledge and know-how are transposable.

3. The purposiveness of cognitive activity is the growth of possibilities, as opposed to reaching a correct and predetermined answer.

4. Every action, operation, conceptual structure or theory is considered viable when it thrives to accomplish a task or reach a fixed goal.

Depending on whether or not the knowledge constructing activity is of an individual or collective nature, these fundamental principles will be applied in different ways (Bruner, 1985; De Vries et Kohlberg, 1990; Tudge \& Rogoff, 1989). These writings advocate the value of individual and internal reality (cognitive constructivism) while emphasizing the importance of knowledge and understanding stemming from social encounters (social constructivism).

Table 1. Principles for Individual and Collective Activity, (See Appendices) explains a categorization of these four principles as applied to both cognitive and social constructivism. Table 2. Principles of Cognitive and Social Constructivism, (See Appendices) explains the categorization of these four principles as applied to both cognitive and social constructivism.

Many factors undoubtedly influence literacy. Like all learning, learning to read is, to a great extent, a social process. The process begins years before children enter school, when they are read to at home. Attitudes about reading are nurtured through this one-to-one reading relationship. This initial phase in the development of the reader is grounded in the social interaction between the child and the adult model. A positive model is one of the keys to becoming a successful reader. School can serve as an extension to the parent-child reading relationship. Teachers, peers and older students can now provide the guidance, support, encouragement, opportunity, and positive environment required by the emergent reader. If learning to read is a social process, then it follows that it is also a cultural process. There are differences among cultures in the ways in which parents teach children at home.

Teachers, therefore, need to be aware of and understand the cultural diversity of the community they serve. Strategies for the teaching of reading should include a variety of enjoyable, interactive, and genuine reading experiences based in a multicultural literature reflective of the learning community. Learning to read and write activates specific language functions. Often we assume that activating the linguistic functions underlying reading does not differ from how children acquire spoken language itself. However, the two processes of acquisition are fundamentally 
different. Because reading, like speech, is an act of communication, teachers are often tempted to approach the teaching of reading through pedagogical strategies of assimilation. However, understanding what the other is saying is not a passive reception, but instead a productive activity.

A teacher can create a rich and diverse writing environment through the use of books to be sure, but also through comic books, magazines, catalogues, special oeuvres, dictionaries, newspapers, websites, billboards, etc. Whether a student flips through an illustrated book or a catalogue, this can constitute a first step towards writing if the teacher in turn knows how to encourage students during this process. The teacher should ensure that the students have access to many writing samples that teach them about the subjects they are interested in. Students will then be able to enjoy rereading different materials on the same subject matter.

During learning situations, reading and writing activities share a dialectic relationship. In other words, the learning of one influences the learning of the other. Nonetheless, teachers must try to create a healthy balance between privileging the reading of texts and the writing of them.

- It is impossible to affirm that one method will always give the best results. Certain methods have not been rigorously evaluated. In general, scientific research only considers one or two methods.

- No single method assures, or produces, equally good results for all students in one class.

- A number of factors influence the results of any given method, such as: the intelligence of students, family environment, the teaching materials used and the ability and personality of the teacher.

Assessing and evaluating student achievement has always been and will remain one of the most important aspects of the total educational process.

There is a broad consensus in the educational community about the basic principles (listed below) that underpin effective assessment and evaluation in classroom settings.

\section{Process of Assessment}

- must be realistic, continuous, purposeful, and systematic;

- is an integral part of the teaching and learning process;

- must be appropriate to the individual learner;

- identifies areas of both strength and weaknesses and recommends appropriate next steps;

- requires a great variety of techniques, devices, and resources;

- requires effective communication;

- begins with clearly stated program expectations at both general and specific levels over short and long-term learning intervals;

- involves ongoing and documented observation supported by a great variety of task-appropriate tools (questionnaires, contracts, rating-scales, audio and video recordings, interviews, quizzes, conferences, charts, checklists, inventories, portfolios, etc.);

- provides feedback regarding both the process and the product of learning; 
- requires collaboration among teachers, students, parents/guardians, and community;

- makes appropriate use of observable, authentic, and relevant enactments of learning;

- fosters learning.

\section{Functions of Evaluation}

The evaluations students receive should reflect what students are expected to learn in the classroom. The expectations associated with the curriculum arise from a variety of social, cultural and psychological processes that reflect the specific makeup and mandate of each school. Consequently, judgments of excellence fulfill a variety of social functions in the school and the surrounding community. As one of its key functions, evaluation is an important means of communicating to the stakeholders outside of the classroom (e.g., administration, parents) information about students' achievements. Furthermore, evaluation aims to ensure that the mission statement of the school is realized. Evaluation helps teachers to fulfill their daily pedagogical functions. The criteria teachers use to evaluate students must not only assess their level of understanding, but also stimulate their inherent desire to learn. Evaluation should examine much more than just the elements of the students' performances of various pedagogical activities. The processes of evaluation should also include an examination of the curriculum, teaching strategies, and educational resources.

In the context of promoting scholastic success amongst students, teachers need to:

- revise expectations and the curricular content as appropriate;

- inform students about their results in order to encourage them to meet expectations;

- $\quad$ verify the pertinence of testing and evaluation methods;

- make the necessary changes and corrections to teaching strategies;

- take note of the achievement gaps among students;

- improve their evaluation tools (testing);

- modify evaluation as appropriate to better respond to the needs of all students.

\section{Study Method}

The principles of pedagogical culture and the research on literacy and constructivist ideology suggest that teachers play a crucial role in implementing desired changes related to the education system (Berger, 2003). With this understanding in mind, the broader study had two objectives: first, to identify successful teaching practices and evaluation tools; and second, to document the changes and process related to the implementation of teaching practices and evaluation tools. More specifically, our study also aimed to answer some questions such as: how do teachers perceive their role in literacy development amongst students of an ethnocultural minority? What are the teaching and evaluation practices that favour literacy learning amongst students of an ethnocultural minority? In order to reach these objectives and answer these research questions, we examined the 
practices and evaluation strategies of Ontario's teachers by way of case studies and an in-depth survey.

In this paper, we report specifically on the quantitative aspect of our research involving Ontario educators' responses to administered questionnaire and research instruments. The study is descriptive as it examines the teaching and assessing practices of teachers, in the context of diversity, in settings that differ in French, English, public and Catholic schools throughout all of Ontario. By combining survey and case study approaches to data collection, the broader study uses a mixed model method (Johnson \& Christensen, 2004) that will yield both broad-based patterns and in-depth details regarding practices in the context of diversity in Ontario.

\section{Participants}

The subjects for this research are Kindergarten to grade 6 teachers working in French and English schools in Ontario. This population of interest is divided into 60 English language district school boards and 12 French language district school boards. The school boards are spread over five general regions: north (8 Eng., 4 Fr.), south (16 Eng., 2 Fr.), east (9 Eng., 3 Fr.), centre (19 Eng., 1 Fr.), and west (8 Eng., 2 Fr.). District school boards vary from very large (more than 100 schools) to very small (less than 25), and cover large and small geographic areas. Boards situated mostly in urban areas typically have a more diverse student population than rural ones, although northern communities include a significant Aboriginal student population. A stratified sample of 8 English boards and 3 French boards representing different regions and board size was randomly selected. See Table 3. School Boards for Survey Questionnaires, in Appendices, for more details about the number of schools accessed and the number of questionnaires sent.

\section{Instrumentation}

\section{Questionnaire}

In order to answer the research questions, a questionnaire was conceived in both languages probing teachers about the strategies they use for literacy and evaluation in the classroom within a diversity setting. This questionnaire used both frequency and Likert-style agreement scales. The underlying themes consisted of involvement towards multiple literacies, use and availability of varied resources (physical and human) as well as teaching strategies and assessment practices. These themes were presented in sections titled Teaching and Evaluation. Respondents' demographics were collected in a third section. The questionnaire took approximately 20 to 30 minutes to complete. Respondents who wished to be contacted for the case study phase of the study could indicate their interest on a coloured sheet at the end of the questionnaire.

The interviews were tape recorded and transcribed. The teachers worked in either English-language or French-language school boards. Interviews, consent forms, instructions, etc. were in the language of the school board. The interviews provided information that will complement the questionnaire data that is being gathered in this research project. Interviews also provided details of how the strategies are 
experienced within the school setting as well as indicate possible adaptations in relation to the context of diversity.

\section{Case Studies}

Using several case studies across the province, we have been able to provide further details on the use of teaching and evaluation strategies in Ontario classrooms. These details will help to provide information about actual instructional and evaluation practices used by teachers teaching literacy and numeracy in the context of diversity. In (Berger, Forgette-Giroux and Dei, 2007), the findings of 15 case studies in English boards and 5 case studies in French boards from four different areas are discussed. For these case studies, teachers were interviewed about their experience of evaluating and teaching literacy and numeracy in the context of diversity.

\section{Procedure}

The research team communicated with the boards in order to solicit participation in this study. The Directors of Education received a letter midSeptember 2006 from the main researchers along with a summary of the research proposal by courier. Reminders were sent by telephone, by email and, on occasion, in person. These boards, both large and small, represented urban and rural settings from all of the regions depicted earlier.

Research participants included current grade teachers and other teachers (e.g., resource teachers) who instructed children from kindergarten through grade six. Anonymity was guaranteed because participants were not asked to provide any selfidentifying information.

A coding system was developed to allow us to trace questionnaires to the boards and participating schools. The codes did not allow for the identification of particular teachers unless they chose to submit their name and contact information for the interview (in which case the information was used solely to establish contact).

Data was collected by surveys, which were sent in packages to the principals of participating schools. These packages contained the surveys for teachers, as well as introductory letters for principals explaining the purpose of the study. Packages were sent to 326 schools, for a total of 4591 surveys distributed. Details regarding the distribution of questionnaires are presented in Table 3 in Appendices. Surveys were distributed to schools between October 2006 and February 2007.

\section{Presentation of Survey Results and Analysis}

Five English school boards and three French school boards agreed to participate in the timeframe possible for this study. Altogether, the boards granted access to 326 schools. Though most boards granted the research team access to all the schools for this study, one chose to limit access to a set number of schools and required direct permission from the principals in order to send the material, and another chose to include only Student Achievement Teachers (SAT) from each school. Questionnaires were distributed to a total of 304 schools. 
With the completed questionnaires, data was integrated in a SPSS program created for this purpose. This allowed the team to organize the responses using the initial coding system, thereby permitting the analysis of survey answers by questions, board, region, language, etc. Cross tabulations between demographic information and responses also permitted other analysis.

\section{Demographic Information}

Respondents revealed through their answers some of the characteristics that described them. Gender wise, 382 women and 64 men returned the questionnaire. Of these teachers, 101 came from Catholic school boards and 345 came from public school boards; 117 worked for French language boards and 340 for English language boards.

\section{Teaching and Grade Level Experience}

Though survey participants are kindergarten to grade eight teachers, the majority of respondents teach first, second and third grades. In the past, most have taught at various grade levels for more than one year; however, fewer have taught junior kindergarten and kindergarten levels in the past. Slightly less than a third of the teachers are in multi-level classes or are teaching more than one grade this year.

The teachers who answered the research questionnaire represent a varied degree of teaching experience, from less than a year (3,6 percent) to over 20 years (20,5 percent), with the largest group (25,45 percent) having 6 to 10 years of teaching experience. See Figure 1. Number of Years Teaching at the Elementary Level, and Figure 2. Level Taught in the Past For at Least a Full Year, in Appendices.

Approximately one third of the schools' student population where the respondents teach are exceptional learners, many with identifiable needs. See Figure 3. School Description (Total Population) in Appendices and Figure 4. School Description (Francophone Population) in Appendices.

The respondents' training in literacy and numeracy occurred mostly during initial teacher education courses or in short training sessions offered by their boards. However, over one quarter of these teachers received more than 5 days' training by their boards, and a similar percentage were trained at a summer institute. A small number of teachers took it upon themselves to do professional development by completing the reading specialist and the library course or ADQ in mathematics. See Figure 4. Training Background in Literacy and Numeracy, in Appendices.

\section{Discussion: Teaching and Pedagogy}

The teacher's role in the acquisition of literacy skills cannot be undervalued. Formal literacy instruction should strive to equip learners with the tools for reading and writing and also help them reflect critically on knowledge. An important task for the classroom teacher is to cultivate the student's ability to read and write at a level that enables the fulfillment of daily needs and aspirations for social success. Students cannot simply be expected to read well. They must also grasp the complex knowledge that guides everyday interactions and social relationships and be prepared to apply knowledge critically to promote social change. To this end, academic achievement is 
only one aspect of literacy success. Such success must also be about social success. This is a huge responsibility for schools, teachers, administrators, students, parents, communities and governments. In fact, the survey responses point to the critical importance of the teacher's knowledge of the cultural background and histories of students in promoting success. Culture, identity, knowledge production and schooling are all linked, and such linkage has implications for the way in which success can be promoted through an open dialogue of contending histories, experiences and cultural backgrounds of learners. Literacy involves working with knowledge of students and teachers, and the academic and social knowledge that is prevalent in a given school environment.

Literacy could utilize embodied knowledges, experience and tacit ways of knowing as raw cultural resources. The learner her/himself must be central to this process. The learner must be made cognizant of the way she/he comes to know knowledge and what are the determining factors. All learners, teachers alike, ought to question and engage in conversation about the ways legitimized knowledges are informed through historic-cultural specific technologies. What, then, are the moments of divergence and convergence with one's local histories and one's local sociocultural ways of meaning making? Learning/knowledge does not exist separate from these local socio-cultural spaces where different bodies communicate through multiple interactions. As indicated in Table 5. Descriptive Statistics (see Appendices), only 27.8 percent of teachers recognize the importance between cultural background and one's capacity for success, or that the learners' local stories were not 'very often' centered within the classroom discussions. Also, when teachers were asked about particular pedagogic activities concerning culture, the responses were collectively inauspicious. For example, 16.5 percent of teachers thought that it was appropriate for students to speak to the class about absence due to reasons relating to cultural issues; 35 percent of teachers were willing to be informed about a new student's origin; 35.7 percent of teachers asked students to speak about their cultural origins; 29.5 percent of teachers included cultural references and examples that students can relate to, be it books, magazines, stories, songs or Web sites. The need for parents of different ethnicities to be encouraged to take part in the everyday life of the classroom was recognized by 14.5 percent of teachers; 18.6 percent of teachers used literacy and numeracy strategies that were appropriate to cultural diversity; 45.5 percent observed the need for students to be exposed to different points of view and ways of thinking, and 20.5 percent of teachers were in agreement about the importance of not treating students from different cultures as a source of conflict. These pertinent issues to literacy all received dispiriting responses from teachers.

In re-thinking literacy then, we need to find ways in which these said sociohistoric-cultural transmissions can form tangible strategies and in which all learners can develop a particular way of thinking that offers one the capacity to transform their governing socio-historic reality. Importantly, the learner is not an outsider through her/his learning experience. More so, learning is very much centered by means of historic specificities and lived experiences (Freire, 1970), where learners are actively involved in their educational process, rather than the learner being viewed as a recipient where knowledge is "deposited" to the learner as object rather than participant. Literacy must approach the socio-historical perspectives of all learners. 
What is the implication for pedagogy? One of the challenges for critical literacy is working with the incommensurability of the socio-historical conditions where learners come to make meaning of their lived reality. Schooling as community is no different. Learners and pedagogues alike come to the 'classroom' with knowledge and with a particular understanding of different socio-historic cultural locations. The problematic lies with the 'body' and what 'body' is given currency in and through 'excellence' and simultaneously endowed with a 'legitimized' knowledge. What political interest do schools serve in their neutral states? How is the 'excellent' body constituted through the dissemination of this objective universalized knowledge? And how can educators and pedagogues transform the 'body' of excellence to include 'other' ways of knowing, 'other' realities, and 'other' lived histories?

Critical literacy is more about pushing against the traditional period when the positivist paradigm, this sense of a value free, objective, non-biased, impartial knowledge and saturated institutionalized ways of learning, was very much the dominant trope (See also Giroux 1983b). Historically, literacy was considered as a body of knowledge, viewed as "out there", external from the body, as distinct and disconnected from one's lived experience and as purely independent of the existing socio-historic-cultural specific technologies, thereby producing and reproducing the designated 'excellent body'. Approaching literacy through a socio-cognitive constructivist paradigm ought to allow for a pedagogy that subverts historic dominant classifications of knowledge and power. All learners ought to be able to self-reflect on their understandings in relation to the broader historic-socio-cultural context. Pedagogy that subverts must utilize, as a raw resource, the learners' capacity to make meaning through their voice and embodied knowledge in order to transform their lived reality. A pedagogy that subverts ought to call upon the communicative possibilities immanent to a lived plural community. In this way, the expert-author posture of literacy, to some extent, is challenged each day by the learners' experiential ways of knowing. This act of communicating is not simply some mere movement of words. It is communicating through the means of conversations that interpret and critically self- reflect on the learners' lived experience.

We can glean from educators' survey responses the importance of integrating students' personal and cultural experiences into literacy and numeracy education. Excellence is enhanced by the educator's ability to generate questioning that values students' knowing and allows all learners to become problem solvers in their own right. Enhanced literacy education must work with students' experiences outside the classroom and promote community values that place a premium on excellence achieved holistically, which fulfills social and academic responsibilities. In promoting literacy and numeracy development, educators must develop high expectations for students. Educators must see the potential in every learner and work with the understanding that all students have within themselves the capacity to succeed. Such acknowledgement is very powerful and has educational value. It will affirm students' home, cultural and off-school knowledge as equally legitimate. It is the responsibility of the educator to assist the learner in developing such knowledge so as to create educational excellence. Critical literacy has much to offer when it is presented as teaching and learning about self, identity and the connections with communities of learners. By teaching about the limitations of learners who are developing a sense of 
entitlement without responsibility to community and citizenship, critical literacy provides possibilities for educational and social transformation. By helping the learner understand his or her place and role in society and the responsibilities of belonging to a community, critical literacy helps create a global learner. Critical literacy then becomes another space and realm where alternative visions of society and possibilities for the future may be created. While schools are contested spaces, educational success requires the joint contributions of educators, students, parents, communities and the state.

Educators' responses confirm our central thesis that critical literacy is the pursuit of the learner's empowerment (through the education that is culturally relevant to learners' experiences) and cannot be attained if students are not encouraged to be critically reflective (see also Aronowitz \& Giroux, 1991). Questions of pedagogy, instruction and texts are central themes of investigation in research on literacy. The culture of schooling, the social relations of knowledge production, social organization of knowledge, the learning environment, classroom instructional methods and processes, schools' curricular materials, formal and informal norms, values and assumptions, as well as educators' expectations of learners are important sites for interrogation of the structures of educational delivery essential for promoting youth literacy.

The classroom must be a space open to different values of communities and groups in a spirit of open dialogue, contestation and search for understanding. The goal is to allow learners to develop not only a deep appreciation of cultures and multiple knowledges, but also an understanding of the place of history, identity, and shared value systems. Students are only going to be open and receptive to different value systems if classroom discussions also reflect on their own histories, experiences and knowledge systems. The ability of a teacher to present cultures through a critical lens can help learners engage with knowledge. Literacy education must aim for cultural integration at multiple levels rather than the simple achievement of a cultural synthesis that homogenizes and obfuscates differences.

\section{Discussion: Evaluation}

In evaluating 'success', literacy education must work with 'success' as based on multiple factors. This will include what is taught to students in and outside the school system. Competency is not simply about reading and writing. It is also about understanding one's social environment, and the socio-political cultural milieus in which education takes place. The implication of this is that any 'measurement' tools educators use to assess literacy must be developed in concert with local communities, parents and students who are partners in the task of ensuring success for diverse learners. These tools must also be contextualized in local understandings of what constitutes educational resource and how such resources are distributed in different communities. These tools must also be made meaningful to the experiences of diverse learners. This is a form of 'cultural groundedness' or rootedness that is required for effective literacy education. Such groundedness is moreover about uncovering multiple knowings and how they shape the experiences of diverse learners. It is also about how an educator works with these different knowledges in a given classroom to 
transfer knowledge successfully. Educators who cultivate different forms of thought, notwithstanding the tension and contradictions of knowledge, are more likely to foster an environment for creative learning and nurture the possibilities of new imaginings to emerge in a spirit of co-operative learning. In essence, this is what multiple literacies are about.

Teacher [in] competence translates to student [in]competence. Competence emerges from participants engaging in knowledge and the learning process. The teacher's knowledge and her/his ability to convey such knowledge to students is a mark of competence. The teacher who exhibits confidence and humility in her/his own knowledge can embolden students. Excellence emerges through a co-operative undertaking where each learner feels a sense of obligation to the other and the school system has built enough support networks and institutional safeguards to assist all learners.

\section{Summary Discussion}

In order to be successful in today's competitive global economy, youth will need to be highly skilled and able to take on the complex tasks the labour market will demand. Education is generally viewed as key to success, and to social mobility in particular. Students' conceptions of success are often tied to a degree of academic achievement that ensures satisfaction (i.e., employment) in the labour market. Literacy is an important aspect of youth education. To be literate is a status symbol that comes with social rewards. Students who lack skills and basic knowledges are always at a disadvantage in terms of accessing the valued goods and services of society. This is precisely why governments promote literacy and numeracy in schools. However, certain key questions need to be addressed, such as how to bring about competence in literacy and numeracy for learners in today's competitive labour market? What are the responsibilities of schools, educators, parents, communities and learners? What accounts for educational success and what are the important markers/indicators/measures of such success? What does it mean to be literate in a consumerist economy? What are the conditions for creating high literacy and numeracy rates in schools? This paper does not attempt to answer all of these questions. However, the focus of discussion has a bearing on how we understand and find answers to some of these questions.

Literacy education cannot be detached from the power relationships of institutions and society (Quigley, 1997; Nieto, 1992). For example, the extent to which students can identify with the learning processes goes a long way to ensuring the creation of a critically literate citizenship. Understanding membership in community, citizenry responsibility and obligations to oneself and others are all elements of 'good and inclusive education'. The experiences of learners marginalized in society, whose Indigenous histories, cultures, languages, and [minority] students' identities and subjectivities are devalued or underprivileged in the school system, suggest that we can expect differences in literate competency levels. The reason is simple: in such educational contexts, learners find it difficult to engage education, what is being taught in schools and the knowledges being disseminated. 
Literacy is a social question linked to race, class, gender, disability, and sexual oppression. Consequently, literacy must connect educational strategies to address power, social inequities and oppression (Auerbach, 1993). Critical literacy can help learners make sense of knowledge and the learning process by grounding schooling and education in the context of the everyday experiences of students. Such experiences must be connected to broader socio-structural and political forces of society. Critical literacy can enhance students' academic and social achievement if the objective of education is to help learners reflect on their individual experiences and to engage in social action for change. The efficacy of critical literacy is that learners are able to understand; not only how education affects work, training and social issues, but how racism, social oppression and socioeconomic status determine life chances for different bodies in society (see also D’Amico, 1999).

Critical literacy also has an important role to play in re-thinking contemporary concepts of 'development'. 'Development', labor markets, and literacy are all discursively steeped in principles and procedures that seek particular geographic interests, particular geographic subjects which promulgate the formation of the 'excellent body'. With the socializing mode of schooling, literacy becomes a product waiting to be consumed resulting in a form of modernization where specific ways of understanding and specific ways of knowing become normalized into Western curricula. Literacy and the co-present pedagogy then becomes idealized, partitioned and institutionalized within the hallways of education, establishing this standard curriculum for all. Education is then materialized and disseminated through these ensuing hierarchal relations into communities, which in turn promote the dominant political interests. Today the 'classroom' is saturated with imperious knowledge systems. Though many counter-hegemonic voices have written/spoken back through the critical spaces of race, class, gender, sexuality and abelism, these voices have still been positioned on the margins or made to operate tangentially to the everyday curriculum of literacy. Critical literacy ought to allow for a multi-centered space that integrates the learners' "personal and cultural experiences" and, at the same time, generates questions that value all learners' heritage. Given the interests and intraconnectedness of globalization, labour markets, and 'development', all of which are constitutive materials of 'modernization', the question of what knowledge is relevant to critical literacy is important.

It is worrisome that, as seen in Table 6. Evaluation (see Appendices), only 23.7 percent of teachers gave students the opportunity to assess their work; 14.5 percent of teachers did assessments in a manner that primarily helped to identify students' shortcomings; 39.1 percent of teachers moved beyond academic achievement to consider students' levels of participation when doing their assessments; 32.1 percent took into account the students' motivation, while 32.3 percent of teachers considered the students' attitude and 39.5 percent shared the evaluation criteria with parents. For the most part, parents are not aware of the expectations that must be met in the literacy and numeracy curricula. As Table 6 reveals, the following occurred frequently in respondents' classrooms: 58.5 percent of educators focused their teaching on elements that made sense to their students; 51.5 percent of teachers conducted assessment that they felt would determine students' 'strong points'; 57.7 percent of teachers felt they made professional judgments 
concerning the assessment of students' general performance in literacy and numeracy; 50.2 percent of teachers thought their literacy and numeracy learning took into account the latest evaluation practices and 60.7 percent of educators based their literacy and numeracy learning on what was taught in the classroom. But what critical literacy is contesting, in this case, are the underlying assumptions that inform these 'elements that make sense to students, and these professional judgments and evaluation practices'. The fact is that the underlying assumptions, professional judgments and evaluation practices are based more on this neutral, objective way of knowing.

Hence, curriculum materials could be more reflective of the diversity of elementary and secondary students, and allow a comfort and familiarity with narratives of Indigenous philosophies on values and character education. Canadian educators could be assisted to engage the curriculum materials through teaching formats such as reading (read aloud, shared reading - small group, pairs, teacher-led), creative writing, speaking and listening, role play/drama, visual arts, songs, gameswith a link of the material with familiar/current experiences and issues outside school (home, community, media). The goals of such curriculum materials is to have in place a body of text material that allows sustained engagement/story development, in a variety of formats and settings, that instill knowledge (stories, visual images, songs) about culture and history and that contains positive political and moral ideas. Students will be able to listen to and respond to stories, have conversations with peers and adults, and be able to integrate material outside the classroom (homes, community) to situate/contextualize heritage/history, and to model/socialize knowledge as behaviour - with real life concepts, resources, and situations.

For example, the use of folktales can introduce students to global cultures and help them recognize that people all over the world are moved by the same emotions. These tales are set in the past and allow students to situate themselves in the undetermined historical contexts of stories. Children's literature offers a variety of tales for different reading levels. Fairytales offer up a universe of never-ending themes. It can be advantageous to introduce these types of stories during trade activities. Often, the appearances of characters, places and actions have symbolic meanings and functions. Fairytales generate a wide range of character archetypes: human, animal, personified objects that experience a succession of adventures. Through characters and circumstances, fundamental values are experienced: courage, love, benevolence, determination, patience, confidence, and self-esteem. As documented stories, folktales stem from the oral traditions of different countries and cultures. As pedagogical tutors using folktales and fairytales, teachers become brilliant storytellers. The art of storytelling is an effective way of preserving and conveying universal images, ideas, motivations and emotions in societies: the importance of helpfulness, solidarity, fantasy, love, etc.

\section{References}

Acker, V., Inzillo, C., \& Lefebvre, B. (2000). Ados, comment les motiver. France: Marabout. 
Aronowitz, S., \& Giroux, H. (1991). Textual Authority. In M.W. Apple and L.K. Christian-Smith, (Eds.). In the Politics of the Textbook (pp. 213-241). New York: Routledge.

Aronowitz, S., \& Giroux, H.A. (1993). Education Still under Siege. South Hadley, MA: Bergin-Garvey.

Auerbach, E. (1993). Putting the P Back in Participatory. TESOL Quarterly, 27 (3), 543-545.

Berger, M.J. (2003). Exploration du portfolio de l'enseignant comme outil de réflexion et de mise en œuvre d'un curriculum. Revue suisse des sciences de l'éducation, 25, (1), 125 -141.

Berger, M.J., Forgette-Giroux, R., \& Dei, G.J.S. (2007). Literacy, Diversity and Education: Meeting the Contemporary Challenge. Forthcoming.

Bruner, J. (1985). Vygotsky: An Historical and conceptual Perspective. Dans J. Wortsch (Ed). Culture, Communication, and Cogntiive: Vygotskian Perspectives (pp.21-34). Cambridge, England: Cambridge University Press.

D’Amico, D. (1999). Politics, Policy, Practice and Personal Responsibility: Adult Education in an Era of Welfare Reform. Boston, MA: National Center for the Study of Adult Learning and Literacy, Harvard University, (Ed. 440-254) http://gseweb.harvard.edu/ ncsall/research/d’amicol.pdf

Dei, G.J.S. (2007). Teaching Discipline, Respect and Character Education: What can be Learned from Schooling in Pluralistic Contexts and Local African Indigenous Teachings. Research proposal submitted to the Literacy and Numeracy Secretariat, Ontario Ministry of Education and Training, Ontario, Toronto.

Dei, G.J.S., James M, I., James-Wilson, S., Karumanchery, L., \& Zine, J. (2000). Removing the margins: The challenges and possibilities of inclusive schooling. Toronto: Canadian Scholar's Press.

De Vries, R. \& Kohlbert, L. (1990). Constructivist Early education: Overview and Comparison with other Programs. Washington, DC: National Association for the Education of Young Children. (Originally published 1987 as Programs of Early Education: The Constructivist View. New York: Longman).

Freire, Paulo. (1970). Pedagogy of the Oppressed. Continuum. New York.

Giroux, H.A. (1983a). Theories of Reproduction and resistance in the New Sociology of Education: A Critical Analysis._Harvard Educational Review 53 (3), 257293.

Giroux, H.A. (1983b). Theory and Resistance in Education: A Pedagogy for the Opposition. Bergin \& Harvey Publishers, Inc. Massachusetts.

Hassett, D. (2006). Signs of the times: The governance of alphabetic print over 'appropriate' and 'natural' reading development. Journal of Early Childhood Literacy, 6 (1), 77-103.

Johnson, B., \& Christensen, L. (2004). Educational research: Quantitative, qualitative, and mixed approaches ( $2^{\text {nd }}$ edition). Boston, MA: Pearson Education Inc.

http://www.tsbvi.edu/Outreach/seehear/spring03/literacy.htm 
Jeynes, W. (2003). A Meta-Analysis: The Effects of Parental Involvement on Minority Children's Academic Achievement. Education and Urban Society, 35, 202-223.

King, J. (1997). Preparing teachers for cultural diversity. Teachers College Press: New York.

Ladson-Billings, G., \& Tate, W.F. (Eds.) (2006). Education Research in the Public Interest: social justice, action and policy. Teachers College Press: New York

Lareau, A., Hovat, E.M. (1999). Moments of Social Inclusion and Exclusion: Race, Class, and Cultural Capital in Family - School Relationship. Sociology of Education, 12 (1), 37-53.

Ministère de l'éducation et de la formation de l'Ontario. (1994). Programme-cadre Aménagement linguistique et Perfectionnement $d u$ français. Paliers élémentaire et secondaire. Toronto.

Ministère de l'éducation et de la formation de l'Ontario. (1997). Le curriculum de l'Ontario de la $1^{\text {ère }}$ à la $8^{e}$ année. Toronto.

Ontario Ministry of Education. (2003). Early Reading Strategy. Toronto, Ontario: Queen's Printer.

Ontario Ministry of Education. (2004). Literacy for Learning. Toronto, Ontario: Queen's Printer.

Ontario Ministry of Education. (2004). Teaching and Learning Mathematics. Toronto, Ontario: Queen’s Printer.

Ontario Ministry of Education. (2005). Education for All. Toronto, Ontario:; Queen’s Printer.

National Research Council and Institute of Medicine. (2004).

Nieto, S. (1992). Affirming Diversity. New York: Longman.

OCDE, (2000). Science, technologie et innovation dans la nouvelle économie.

Quigley, A. (1997). Rethinking Literacy Education: The Critical need for Practice Based Change. San Francisco: Jossey-Bass.

Krugly-Smolska, S.E.E., \& Warren, L.W. (2001). Academic Achievement of Adolescents from selected Ethnocultural Groups in Canada: A Study Consistent with John Ogbu’s Theory. McGill Journal of Education, 3 (1), 6171.

Statistics Canada. (2002). 2001 Census: Analysis Series, Profile of languages in Canada: English, French and many others. Ottawa, Ontario: Ministry of Industry.

Solomon, R.P., \& Sekayi, N.R.D. (Eds.) (2007). Urban teacher education and teaching: Innovative practices for diversity and social justice. Mahwah, N.J. Lawrence Erlbaum Associates.

Tudge, J. \& Rogoff, B. (1989). Peer Influences on Cognitive Development: Piagettian and Vygotskian Perspectives. In M. Bernstein \& J. Bruner (Eds.), Interaction in Human Development: Piagettian and Vygotskian Perspectives. In M. Bernstein \& J. Bruner (Eds.), Intercation in Human Development (pp. 17-40). Hillsdale, NJ: Erlbaum.

Van Der Veer, R. \& Valsiner, J. (Eds.) (1994). The Vygotsky Reader. Blackwood, NJ : Blackwell. 
Villegas, A., \& Lucas, T. (2002). Preparing culturally responsive teachers: Rethinking the curriculum. Journal of Teacher Education, 53 (1), 20-32. 


\section{Appendices}

Table 1. Principles for Individual and Collective Activity

\begin{tabular}{|c|c|}
\hline \multicolumn{2}{|l|}{ 1. Cognitive and Metacognitive Factors } \\
\hline $\begin{array}{l}\text { Nature of the Literacy and Numeracy } \\
\text { Learning Process: }\end{array}$ & $\begin{array}{l}\text { Pedagogical Strategies Stemming from these } \\
\text { Factors: }\end{array}$ \\
\hline $\begin{array}{l}\text { The learning of complex material is best } \\
\text { approached by students with the } \\
\text { intention of deciphering the meanings of } \\
\text { texts with the assistance of available } \\
\text { information and their own experiences. }\end{array}$ & $\begin{array}{l}\text { - Favour processes that enable students to master } \\
\text { complex subject matter. } \\
\text { - } \text { Instruct students to use their own knowledge to } \\
\text { help guide them in the process. } \\
\text { Encourage students to be aware of their own } \\
\text { conceptions of learning and to adhere to the } \\
\text { one that favours the search for meaning. }\end{array}$ \\
\hline $\begin{array}{l}\text { Successful students are those who, with } \\
\text { time and pedagogical assistance, } \\
\text { become fully aware of the knowledge } \\
\text { that must be acquired in relation to a } \\
\text { specific field of study. }\end{array}$ & $\begin{array}{l}\text { Encourage students to set short-term objectives } \\
\text { in order to acquire specific knowledge of the } \\
\text { field of study. } \\
\text { - Gradually encourage students to pursue longer- } \\
\text { term objectives. }\end{array}$ \\
\hline $\begin{array}{l}\text { Successful students are those who can } \\
\text { efficiently link new knowledge with } \\
\text { previously acquired knowledge. }\end{array}$ & $\begin{array}{l}\text { Encourage students to develop their ability to } \\
\text { create links between previously acquired and } \\
\text { newly acquired information. This can be done } \\
\text { by adding new knowledge, replacing existing } \\
\text { knowledge, modifying, or reorganizing } \\
\text { knowledge. }\end{array}$ \\
\hline $\begin{array}{l}\text { Successful students are those who can } \\
\text { create and utilize a repertoire of } \\
\text { reasoning strategies in order to reach } \\
\text { their learning goals. }\end{array}$ & $\begin{array}{l}\text { - Broaden students' repertoire of strategies. } \\
\text { - Help them recognize the advantages and } \\
\text { disadvantages of each strategy. } \\
\text { - Encourage students to develop meta-cognitive } \\
\text { strategies. }\end{array}$ \\
\hline
\end{tabular}




\begin{tabular}{|c|c|}
\hline \multicolumn{2}{|l|}{ 2. Motivational and Affective Factors } \\
\hline $\begin{array}{l}\text { Nature of the Literacy and Numeracy } \\
\text { Learning Process: }\end{array}$ & $\begin{array}{l}\text { Pedagogical Strategies Stemming from these } \\
\text { Factors: }\end{array}$ \\
\hline $\begin{array}{l}\text { The quality and amount of knowledge } \\
\text { acquired are influenced by the learner's } \\
\text { motivation. In return, the learner's } \\
\text { motivation is influenced by his or her } \\
\text { emotions, beliefs, interests, goals, and } \\
\text { thinking ability. }\end{array}$ & $\begin{array}{l}\text { - Create a work atmosphere that is agreeable and } \\
\text { that fosters happiness and encourages curiosity. } \\
\text { - Avoid competitive activities that provoke } \\
\text { anxiety. } \\
\text { - Favour activities where everyone is a winner. }\end{array}$ \\
\hline $\begin{array}{l}\text { Creativity, a superior thought process (i.e. } \\
\text { analysis, critical analysis, synthesis), and } \\
\text { natural curiosity all contribute to students' } \\
\text { motivation to learn. Students' intrinsic } \\
\text { motivation is stimulated by activities that } \\
\text { are related to their personal interests and } \\
\text { that allow them to maintain a level of } \\
\text { control over their learning. }\end{array}$ & $\begin{array}{l}\text { - Help students develop the following feelings: } \\
\text { - a sense of proficiency, } \\
\text { - a sense of having control over what he or } \\
\text { she is doing. } \\
\text { - Give meaning to what the student is learning. }\end{array}$ \\
\hline $\begin{array}{l}\text { Acquiring complex knowledge and } \\
\text { abilities requires great effort and } \\
\text { guidance. Students must be intrinsically } \\
\text { motivated to learn in order to generate the } \\
\text { effort required to meet their learning } \\
\text { goals. }\end{array}$ & $\begin{array}{l}\text { - Create learning activities that are relevant to } \\
\text { students and tailored to their learning needs. }\end{array}$ \\
\hline
\end{tabular}




\begin{tabular}{|c|c|}
\hline \multicolumn{2}{|l|}{ 3. Developmental and Social Factors } \\
\hline $\begin{array}{l}\text { Nature of the Literacy and Numeracy } \\
\text { Learning Process: }\end{array}$ & $\begin{array}{l}\text { Pedagogical Strategies Stemming from these } \\
\text { Factors: }\end{array}$ \\
\hline $\begin{array}{l}\text { Individuals will encounter many } \\
\text { opportunities and challenges over the } \\
\text { course of their development. Learning is } \\
\text { most efficient when developmental } \\
\text { differences in the following areas are } \\
\text { taken into consideration: physical, } \\
\text { intellectual, emotional, social. }\end{array}$ & $\begin{array}{l}\text { - Provide resource material that: } \\
\text { - is appropriate to the learner's level of } \\
\text { development; } \\
\text { - is introduced in an agreeable and adequate } \\
\text { fashion; } \\
\text { - provides encouragement to students in the } \\
\text { fields that present the most challenges for } \\
\text { them; } \\
\text { - instructs parents on how to adequately } \\
\text { intervene. }\end{array}$ \\
\hline $\begin{array}{l}\text { A student's learning is influenced by } \\
\text { social interactions, personal } \\
\text { relationships, and communication with } \\
\text { others. }\end{array}$ & $\begin{array}{l}\text { - Support activities that: } \\
\text { - favour interaction and collaboration with } \\
\text { other students while they accomplish a task; } \\
\text { - favour student social interaction; } \\
\text { - respect individual differences; } \\
\text { - value open-mindedness and social skills. }\end{array}$ \\
\hline
\end{tabular}




\begin{tabular}{|c|c|}
\hline 4. Individual Differences & \\
\hline $\begin{array}{l}\text { Nature of the Literacy and Numeracy } \\
\text { Learning Process: }\end{array}$ & $\begin{array}{l}\text { Pedagogical Strategies Stemming from these } \\
\text { Factors: }\end{array}$ \\
\hline $\begin{array}{l}\text { Students each possess learning abilities, } \\
\text { approaches, and strategies that are based } \\
\text { on personal experience and heredity. }\end{array}$ & $\begin{array}{l}\text { - Analyze students' preferences according to: } \\
\text { - their way of learning } \\
\text { - their learning pace }\end{array}$ \\
\hline $\begin{array}{l}\text { Learning requires high teaching } \\
\text { standards and realistic challenges. } \\
\text { Students, as well as their ways of } \\
\text { learning, should be evaluated. }\end{array}$ & $\begin{array}{l}\text { - Put the information obtained through evaluations } \\
\text { to good use. } \\
\text { - Recognize: } \\
\text { - students' strong and weak cognitive abilities } \\
\text { - students' knowledge and abilities } \\
\text { - Utilize the information obtained through } \\
\text { evaluations to help: } \\
\text { - select the learning material that will be most } \\
\text { beneficial } \\
\text { - oversee the progression of learning } \\
\text { objectives } \\
\text { - Motivate students to pursue learning objectives } \\
\text { by: } \\
\text { - providing feedback } \\
\text { - favouring self-evaluation } \\
\text { - Document the decisions that must be made with } \\
\text { the help of information obtained through } \\
\text { evaluations. }\end{array}$ \\
\hline $\begin{array}{l}\text { Learning is most efficient when linguistic, } \\
\text { cultural, and social differences are taken } \\
\text { into account. }\end{array}$ & $\begin{array}{l}\text { - Plan learning activities that consider such factors } \\
\text { as: } \\
\text { - language, ethnic background and beliefs. }\end{array}$ \\
\hline
\end{tabular}


Table 2. Principles of Cognitive and Social Constructivism

\begin{tabular}{|c|c|c|}
\hline $\begin{array}{l}\text { Fundamental } \\
\text { Principles }\end{array}$ & $\begin{array}{l}\text { Cognitive } \\
\text { Constructivism }\end{array}$ & Social Constructivism \\
\hline $\begin{array}{l}\text { 1. Individual or social } \\
\text { activity is } \\
\text { necessary for the } \\
\text { construction of } \\
\text { knowledge. }\end{array}$ & $\begin{array}{l}\text { The construction of } \\
\text { knowledge is the result } \\
\text { of an interaction } \\
\text { between the individual } \\
\text { and his environment, } \\
\text { which undergoes } \\
\text { information processing. }\end{array}$ & $\begin{array}{l}\text { In a social setting, the construction } \\
\text { of knowledge is not only the result } \\
\text { of an interaction between the } \\
\text { individual and his environment, but } \\
\text { also between two or more } \\
\text { individuals. }\end{array}$ \\
\hline $\begin{array}{l}\text { 2. Knowledge and } \\
\text { know-how are } \\
\text { transposable. }\end{array}$ & $\begin{array}{l}\text { In order to learn, an } \\
\text { individual must acquire } \\
\text { tools and implement } \\
\text { them. }\end{array}$ & $\begin{array}{l}\text { In a group, the construction of } \\
\text { knowledge is the result of an active } \\
\text { interaction between two or more } \\
\text { individuals who acquired tools and } \\
\text { implemented them. }\end{array}$ \\
\hline $\begin{array}{l}\text { 3. The purposiveness } \\
\text { of cognitive } \\
\text { activity is the } \\
\text { growth of } \\
\text { possibilities as } \\
\text { opposed to } \\
\text { reaching a correct } \\
\text { and predetermined } \\
\text { answer. }\end{array}$ & $\begin{array}{l}\text { Individuals have their } \\
\text { own mental conception } \\
\text { of reality. }\end{array}$ & $\begin{array}{l}\text { Reality can emerge through the } \\
\text { interaction between two or more } \\
\text { individuals who, as a result, will } \\
\text { share a common reality. }\end{array}$ \\
\hline $\begin{array}{l}\text { 4. Every action, } \\
\text { operation, } \\
\text { conceptual } \\
\text { structure or theory } \\
\text { is considered viable } \\
\text { when it thrives to } \\
\text { accomplish a task } \\
\text { or reach a fixed } \\
\text { goal. }\end{array}$ & $\begin{array}{l}\text { An activity is logical to } \\
\text { a learner only if it } \\
\text { responds to an } \\
\text { immediate need. }\end{array}$ & $\begin{array}{l}\text { Acculturation through social } \\
\text { interaction allows for the } \\
\text { construction of knowledge in an } \\
\text { authenticated perspective of } \\
\text { activities. }\end{array}$ \\
\hline
\end{tabular}


Table 3: School Boards for Survey Questionnaires

\begin{tabular}{|c|c|c|}
\hline $\begin{array}{c}\text { Conseils/ } \\
\text { Boards }\end{array}$ & $\begin{array}{c}\text { Nombre d'écoles } \\
\text { avec accès / } \\
\text { Number of schools } \\
\text { with access }\end{array}$ & $\begin{array}{c}\text { Questionnaires envoyés/ } \\
\text { Questionnaires sent }\end{array}$ \\
\hline $\mathrm{A}$ & 41 & 762 \\
\hline $\mathrm{B}$ & 37 & 647 \\
\hline $\mathrm{C}$ & 25 & 322 \\
\hline $\mathrm{D}$ & 147 & 2954 \\
\hline $\mathrm{E}$ & 27 & 102 \\
\hline $\mathrm{F}$ & 10 & 9 \\
\hline $\mathrm{G}$ & 9 & 399 \\
\hline $\mathrm{H}$ & 30 & $\mathrm{n}=4591$ \\
\hline $\mathrm{n}=8$ & $\mathrm{n}=326$ & 296 \\
\hline
\end{tabular}

Table 4. School Participation

\begin{tabular}{|l|c|c|c|c|}
\hline Conseils/ Boards & $\begin{array}{l}\text { Nombre } \\
\text { d'écoles avec } \\
\text { accès / } \\
\text { Number of } \\
\text { schools with } \\
\text { access }\end{array}$ & $\begin{array}{l}\text { Nombre } \\
\text { d'écoles ayant } \\
\text { participé / } \\
\text { Number of } \\
\text { schools that } \\
\text { participated }\end{array}$ & $\begin{array}{l}\text { Participation } \\
\text { des écoles en } \\
\text { pourcentage / } \\
\text { Participation } \\
\text { of schools - } \\
\text { percentage }\end{array}$ & $\begin{array}{l}\text { Questionnaire } \\
\text { s reçus / } \\
\text { Questionnaire } \\
\text { s received }\end{array}$ \\
\hline A Windsor-Essex & 41 & 17 & $42 \%$ & 34 \\
\hline B Centre-Est & 37 & 23 & $62 \%$ & 67 \\
\hline C Lakehead & 25 & 16 & $64 \%$ & 32 \\
\hline D Thames Valley & 147 & 83 & $57 \%$ & 230 \\
\hline E Centre-Sud-Ouest & 27 & 15 & $56 \%$ & 30 \\
\hline F Grand-Nord & 10 & 7 & $70 \%$ & 20 \\
\hline G Rainy River & 17 & 14 & $100 \%$ & 9 \\
\hline H York Region & & & $82 \%$ & 35 \\
\hline
\end{tabular}




\section{Table 5. Descriptive Statistics}

Teaching: To what extent do you agree or disagree with each of the following statements?

\begin{tabular}{|c|c|c|c|c|c|}
\hline & Agree & $\begin{array}{c} \pm \\
\pm \\
\text { Agree }\end{array}$ & $\begin{array}{c} \pm \\
\text { Disagree }\end{array}$ & Disagree & $\mathbf{N} / \mathbf{A}$ \\
\hline $\begin{array}{l}\text { 1. All students should regularly have the opportunity to talk in } \\
\text { class about the activities in which they take part outside of } \\
\text { school. }\end{array}$ & $\begin{array}{l}66 \% \\
(309)\end{array}$ & $\begin{array}{l}27,4 \% \\
(128)\end{array}$ & $\begin{array}{l}3,8 \% \\
(18)\end{array}$ & $\begin{array}{l}0,2 \% \\
(1)\end{array}$ & $\begin{array}{l}2,6 \% \\
(12)\end{array}$ \\
\hline $\begin{array}{l}\text { 2. All students should have the opportunity to introduce } \\
\text { individuals who are important to them in their life other than } \\
\text { their parents. }\end{array}$ & $\begin{array}{l}56,8 \% \\
(266)\end{array}$ & $\begin{array}{l}35,5 \% \\
(166)\end{array}$ & $\begin{array}{l}3,4 \% \\
(16)\end{array}$ & $\begin{array}{l}, 6 \% \\
(3)\end{array}$ & $\begin{array}{l}3,6 \% \\
(17)\end{array}$ \\
\hline $\begin{array}{l}\text { 3. The concept of academic success is the same in most } \\
\text { cultures. }\end{array}$ & $\begin{array}{l}8,5 \% \\
(40)\end{array}$ & $\begin{array}{l}23,3 \% \\
(109)\end{array}$ & $\begin{array}{l}41,9 \% \\
(196)\end{array}$ & $\begin{array}{l}22 \% \\
(103)\end{array}$ & $\begin{array}{l}4,3 \% \\
(20)\end{array}$ \\
\hline $\begin{array}{l}\text { 4. Cultural background can manifest itself through body } \\
\text { language. }\end{array}$ & $\begin{array}{l}53,2 \% \\
(249)\end{array}$ & $\begin{array}{l}29,3 \% \\
(137)\end{array}$ & $\begin{array}{l}4,3 \% \\
(20)\end{array}$ & $\begin{array}{l}, 6 \% \\
(3)\end{array}$ & $\begin{array}{l}12,6 \% \\
(59)\end{array}$ \\
\hline $\begin{array}{l}\text { 5. Cultural background can manifest itself through one's } \\
\text { relationship with authority. }\end{array}$ & $\begin{array}{l}56,2 \% \\
(263)\end{array}$ & $\begin{array}{l}26,3 \% \\
(123)\end{array}$ & $\begin{array}{l}3,2 \% \\
(15)\end{array}$ & $\begin{array}{l}1,1 \% \\
(5)\end{array}$ & $\begin{array}{l}13,2 \% \\
(62)\end{array}$ \\
\hline $\begin{array}{l}\text { 6. Cultural background can manifest itself through one's } \\
\text { capacity for success. }\end{array}$ & $\begin{array}{l}27,8 \% \\
(130)\end{array}$ & $\begin{array}{l}30,3 \% \\
(142)\end{array}$ & $\begin{array}{l}19 \% \\
(89)\end{array}$ & $\begin{array}{l}8,3 \% \\
(39)\end{array}$ & $\begin{array}{l}14,5 \% \\
(68)\end{array}$ \\
\hline $\begin{array}{l}\text { 7. Literacy and numeracy education must consider the learning } \\
\text { style of all students. }\end{array}$ & $\begin{array}{l}83,5 \% \\
(391)\end{array}$ & $\begin{array}{l}12,8 \% \\
(60)\end{array}$ & $\begin{array}{l}, 9 \% \\
(4)\end{array}$ & $\begin{array}{l}, 4 \% \\
(2)\end{array}$ & $\begin{array}{l}2,4 \% \\
(11)\end{array}$ \\
\hline $\begin{array}{l}\text { 8. High expectations must be maintained for all students } \\
\text { concerning literacy and numeracy. }\end{array}$ & $\begin{array}{l}68,4 \% \\
(320)\end{array}$ & $\begin{array}{l}25,4 \% \\
(119)\end{array}$ & $\begin{array}{l}3,2 \% \\
(15)\end{array}$ & $\begin{array}{l}, 6 \% \\
(3)\end{array}$ & $\begin{array}{l}2,4 \% \\
(11)\end{array}$ \\
\hline \multirow{3}{*}{$\begin{array}{l}\text { 9. Literacy and numeracy education must: } \\
\text { - integrate students' personal and cultural experiences; } \\
\text { - generate questioning that values students; } \\
\text { - allow children to problem-solve. }\end{array}$} & $\begin{array}{l}67,1 \% \\
(314)\end{array}$ & $\begin{array}{l}26,3 \% \\
(123)\end{array}$ & $\begin{array}{l}3,2 \% \\
(15)\end{array}$ & $\begin{array}{l}4 \% \\
(2)\end{array}$ & $\begin{array}{l}3 \% \\
(14)\end{array}$ \\
\hline & $\begin{array}{l}78,8 \% \\
(369)\end{array}$ & $\begin{array}{l}16,9 \% \\
(79)\end{array}$ & $\begin{array}{l}, 4 \% \\
(2)\end{array}$ & $\begin{array}{l}, 4 \% \\
(2)\end{array}$ & $\begin{array}{l}3,4 \% \\
(16)\end{array}$ \\
\hline & $\begin{array}{l}86,1 \% \\
(403)\end{array}$ & $\begin{array}{l}10,5 \% \\
(49)\end{array}$ & $\begin{array}{l}, 4 \% \\
(2)\end{array}$ & $\begin{array}{l}, 2 \% \\
(1)\end{array}$ & $\begin{array}{l}2,8 \% \\
(13)\end{array}$ \\
\hline \multirow{2}{*}{$\begin{array}{l}\text { 10. Literacy and numeracy education must consider: } \\
\text { - students' experiences outside the classroom; } \\
\text { - community values. }\end{array}$} & $\begin{array}{l}69,7 \% \\
(326)\end{array}$ & $\begin{array}{l}25,2 \% \\
(118)\end{array}$ & $\begin{array}{l}2,4 \% \\
(11)\end{array}$ & $\begin{array}{l}, 4 \% \\
(2)\end{array}$ & $\begin{array}{l}2,4 \% \\
(11)\end{array}$ \\
\hline & $\begin{array}{l}59,6 \% \\
(279)\end{array}$ & $\begin{array}{l}30,3 \% \\
(142)\end{array}$ & $\begin{array}{l}5,1 \% \\
(24)\end{array}$ & $\begin{array}{l}, 9 \% \\
(4)\end{array}$ & $\begin{array}{l}4,1 \% \\
(19)\end{array}$ \\
\hline \multirow[t]{3}{*}{$\begin{array}{l}\text { 11. Literacy and numeracy education includes: } \\
\text { - a pedagogical approach based on oral expression; }\end{array}$} & $\begin{array}{l}60,7 \% \\
(284)\end{array}$ & $\begin{array}{l}29,5 \% \\
(138)\end{array}$ & $\begin{array}{l}3,8 \% \\
(18)\end{array}$ & $\begin{array}{l}, 6 \% \\
(3)\end{array}$ & $\begin{array}{l}5,3 \\
(25)\end{array}$ \\
\hline & $\begin{array}{l}66,7 \% \\
(312)\end{array}$ & $\begin{array}{l}28,8 \% \\
(135)\end{array}$ & $\begin{array}{l}, 6 \% \\
(3)\end{array}$ & $\begin{array}{l}, 4 \% \\
(2)\end{array}$ & $\begin{array}{l}3,4 \% \\
(16)\end{array}$ \\
\hline & $\begin{array}{l}60,5 \% \\
(283)\end{array}$ & $\begin{array}{l}29,9 \% \\
(140)\end{array}$ & $\begin{array}{l}3,8 \% \\
(18)\end{array}$ & $\begin{array}{l}, 4 \% \\
(2)\end{array}$ & $\begin{array}{l}5,3 \% \\
(25)\end{array}$ \\
\hline $\begin{array}{l}\text { 12. Students should be encouraged to share structural elements } \\
\text { of their first language with the rest of the class. }\end{array}$ & $\begin{array}{l}33,8 \% \\
(153)\end{array}$ & $\begin{array}{l}37,4 \% \\
(175)\end{array}$ & $\begin{array}{l}12,4 \% \\
(58)\end{array}$ & $\begin{array}{l}3 \% \\
(14)\end{array}$ & $\begin{array}{l}13,5 \% \\
(63)\end{array}$ \\
\hline
\end{tabular}


How often does the following happen in your classroom? 


\begin{tabular}{|c|c|c|c|c|c|}
\hline & $\begin{array}{l}\text { Very } \\
\text { often }\end{array}$ & Often & Sometimes & Seldom & $\mathbf{N} / \mathbf{A}$ \\
\hline $\begin{array}{l}\text { 13. When values other than my own are } \\
\text { discussed by students I have difficulty being } \\
\text { open and receptive. }\end{array}$ & $\begin{array}{l}1,1 \% \\
(5)\end{array}$ & $\begin{array}{l}2,4 \% \\
(11)\end{array}$ & $\begin{array}{l}29,1 \% \\
(136)\end{array}$ & $\begin{array}{l}64,1 \% \\
(300)\end{array}$ & $\begin{array}{l}3,4 \% \\
(16)\end{array}$ \\
\hline $\begin{array}{l}\text { 14. Students have the opportunity to discuss } \\
\text { their family or people from their community in } \\
\text { class. }\end{array}$ & $\begin{array}{l}37,2 \% \\
(174)\end{array}$ & $\begin{array}{l}42,1 \% \\
(197)\end{array}$ & $\begin{array}{l}17,3 \% \\
(81)\end{array}$ & $\begin{array}{l}1,1 \% \\
(5)\end{array}$ & $\begin{array}{l}2,4 \% \\
(11)\end{array}$ \\
\hline $\begin{array}{l}\text { 15. If a student is absent for a reason related to } \\
\text { culture, I ask him or her to talk about it to the } \\
\text { class if I deem it appropriate. }\end{array}$ & $\begin{array}{l}16,5 \% \\
(77)\end{array}$ & $\begin{array}{l}24,8 \% \\
(116)\end{array}$ & $\begin{array}{l}31,2 \% \\
(146)\end{array}$ & $\begin{array}{l}13,2 \% \\
(62)\end{array}$ & $\begin{array}{l}14,3 \% \\
(67)\end{array}$ \\
\hline $\begin{array}{l}\text { 16. When a new student comes to class, I inform } \\
\text { myself of his or her origin. }\end{array}$ & $\begin{array}{l}35 \% \\
(164)\end{array}$ & $\begin{array}{l}28,4 \% \\
(133)\end{array}$ & $\begin{array}{l}17,7 \% \\
(83)\end{array}$ & $\begin{array}{l}6,2 \% \\
(29)\end{array}$ & $\begin{array}{l}12,6 \% \\
(59)\end{array}$ \\
\hline $\begin{array}{l}\text { 17. When discussing a culture that is different } \\
\text { from that of the majority of the class, I do it in a } \\
\text { positive manner for the students who belong to } \\
\text { it. }\end{array}$ & $\begin{array}{l}73,3 \% \\
(343)\end{array}$ & $\begin{array}{l}19,4 \% \\
(91)\end{array}$ & $\begin{array}{l}2,8 \% \\
(13)\end{array}$ & $\begin{array}{l}1,3 \% \\
(6)\end{array}$ & $\begin{array}{l}3,2 \% \\
(15)\end{array}$ \\
\hline $\begin{array}{l}\text { 18. I ask my students to talk about their cultural } \\
\text { origins. }\end{array}$ & $\begin{array}{l}35,7 \% \\
(167)\end{array}$ & $\begin{array}{l}32,9 \% \\
(154)\end{array}$ & $\begin{array}{l}25 \% \\
(117)\end{array}$ & $\begin{array}{l}3,2 \% \\
(15)\end{array}$ & $\begin{array}{l}3,2 \% \\
(15)\end{array}$ \\
\hline $\begin{array}{l}\text { 19. While teaching, I incorporate cultural } \\
\text { references and examples that my students can } \\
\text { relate to. }\end{array}$ & $\begin{array}{l}29,5 \% \\
(138)\end{array}$ & $\begin{array}{l}40 \% \\
(187)\end{array}$ & $\begin{array}{l}23,1 \% \\
(108)\end{array}$ & $\begin{array}{l}3,8 \% \\
(18)\end{array}$ & $\begin{array}{l}3,6 \% \\
(17)\end{array}$ \\
\hline $\begin{array}{l}\text { 20. I consult books, magazines or Web sites that } \\
\text { provide information on strategies to use in a } \\
\text { culturally diverse classroom. }\end{array}$ & $\begin{array}{l}13 \% \\
(61)\end{array}$ & $\begin{array}{l}22,9 \% \\
(107)\end{array}$ & $\begin{array}{l}39,7 \% \\
(186)\end{array}$ & $\begin{array}{l}20,3 \% \\
(95)\end{array}$ & $\begin{array}{l}4,1 \% \\
(19)\end{array}$ \\
\hline 21. I use stories and songs from various cultures. & $\begin{array}{l}20,5 \% \\
(96)\end{array}$ & $\begin{array}{l}31,2 \% \\
(146)\end{array}$ & $\begin{array}{l}35,7 \% \\
(167)\end{array}$ & $\begin{array}{l}9,8 \% \\
(46)\end{array}$ & $\begin{array}{l}2,8 \% \\
(13)\end{array}$ \\
\hline $\begin{array}{l}\text { 22. In my classroom, there are posters and } \\
\text { brochures showcasing/presenting cultural } \\
\text { activities in the community (i.e. festivals \& } \\
\text { shows). }\end{array}$ & $\begin{array}{l}9,2 \% \\
(43)\end{array}$ & $\begin{array}{l}15,8 \% \\
(74)\end{array}$ & $\begin{array}{l}38,5 \% \\
(180)\end{array}$ & $\begin{array}{l}32 \% \\
(150)\end{array}$ & $\begin{array}{l}4,5 \% \\
(21)\end{array}$ \\
\hline $\begin{array}{l}\text { 23. I borrow books from the library that } \\
\text { showcase different cultures for the class. }\end{array}$ & $\begin{array}{l}18,8 \% \\
(88)\end{array}$ & $\begin{array}{l}29,1 \% \\
(136)\end{array}$ & $\begin{array}{l}36,3 \% \\
(170)\end{array}$ & $\begin{array}{l}12,4 \% \\
(58)\end{array}$ & $\begin{array}{l}3,4 \% \\
(16)\end{array}$ \\
\hline $\begin{array}{l}\text { 24. I expose my students to artistic activities } \\
\text { representing different cultures. }\end{array}$ & $\begin{array}{l}14,7 \% \\
(69)\end{array}$ & $\begin{array}{l}31,4 \% \\
(147)\end{array}$ & $\begin{array}{l}34,8 \% \\
(163)\end{array}$ & $\begin{array}{l}15,8 \% \\
(74)\end{array}$ & $\begin{array}{l}3,2 \% \\
(15)\end{array}$ \\
\hline $\begin{array}{l}\text { 25. Students in my class are exposed to music } \\
\text { from various cultures. }\end{array}$ & $\begin{array}{l}16,5 \% \\
(77)\end{array}$ & $\begin{array}{l}27,8 \% \\
(130)\end{array}$ & $\begin{array}{l}40,8 \% \\
(191)\end{array}$ & $\begin{array}{l}10 \% \\
(47)\end{array}$ & $\begin{array}{l}4,9 \% \\
(23)\end{array}$ \\
\hline $\begin{array}{l}\text { 26. I collaborate with colleagues from different } \\
\text { cultures in my school. }\end{array}$ & $\begin{array}{l}20,7 \% \\
(97)\end{array}$ & $\begin{array}{l}22,4 \% \\
(105)\end{array}$ & $\begin{array}{l}23,1 \% \\
(108)\end{array}$ & $\begin{array}{l}20,1 \% \\
(94)\end{array}$ & $\begin{array}{l}13,7 \% \\
(64)\end{array}$ \\
\hline $\begin{array}{l}\text { 27. Guests of various cultures come and speak to } \\
\text { my class. }\end{array}$ & $\begin{array}{l}3 \% \\
(14)\end{array}$ & $\begin{array}{l}9,4 \% \\
(44)\end{array}$ & $\begin{array}{l}36,8 \% \\
(172)\end{array}$ & $\begin{array}{l}46,6 \\
(218)\end{array}$ & $\begin{array}{l}4,3 \% \\
(20)\end{array}$ \\
\hline $\begin{array}{l}\text { 28. I encourage support from the members of } \\
\text { various cultures in organizing classroom activities }\end{array}$ & $\begin{array}{l}4,5 \% \\
(21)\end{array}$ & $\begin{array}{l}11,3 \% \\
(53)\end{array}$ & $\begin{array}{l}31,8 \% \\
(149)\end{array}$ & $\begin{array}{l}46,4 \% \\
(217)\end{array}$ & $\begin{array}{l}6 \% \\
(28)\end{array}$ \\
\hline
\end{tabular}




\begin{tabular}{|c|c|c|c|c|c|}
\hline & $\begin{array}{l}\text { Very } \\
\text { often }\end{array}$ & Often & Sometimes & Seldom & N/A \\
\hline $\begin{array}{l}\text { 29. I highlight culturally relevant holidays in } \\
\text { class. }\end{array}$ & $\begin{array}{l}19,4 \% \\
(91)\end{array}$ & $\begin{array}{l}26,1 \% \\
(122)\end{array}$ & $\begin{array}{l}35,3 \% \\
(165)\end{array}$ & $\begin{array}{l}14,7 \% \\
(69)\end{array}$ & $\begin{array}{l}4,5 \% \\
(21)\end{array}$ \\
\hline $\begin{array}{l}\text { 30. I encourage parents from different } \\
\text { ethnicities to take part in class activities related } \\
\text { to cultural holidays. }\end{array}$ & $\begin{array}{l}9,2 \% \\
(43)\end{array}$ & $\begin{array}{l}17,5 \% \\
(82)\end{array}$ & $\begin{array}{l}35,3 \% \\
(165)\end{array}$ & $\begin{array}{l}30,6 \% \\
(143)\end{array}$ & $\begin{array}{l}7,5 \% \\
(35)\end{array}$ \\
\hline $\begin{array}{l}\text { 31. I encourage parents from different } \\
\text { ethnicities to take part in the everyday life of } \\
\text { the classroom. }\end{array}$ & $\begin{array}{l}14,5 \% \\
(68)\end{array}$ & $\begin{array}{l}21,8 \% \\
(102)\end{array}$ & $\begin{array}{l}28,2 \% \\
(132)\end{array}$ & $\begin{array}{l}26,7 \% \\
(125)\end{array}$ & $\begin{array}{l}8,8 \% \\
(41)\end{array}$ \\
\hline $\begin{array}{l}\text { 32. In my class, I discuss with students how to } \\
\text { be respectful of different cultures. }\end{array}$ & $\begin{array}{l}60,5 \% \\
(283)\end{array}$ & $\begin{array}{l}27,6 \% \\
(129)\end{array}$ & $\begin{array}{l}6,6 \% \\
(31)\end{array}$ & $\begin{array}{l}1,5 \% \\
(7)\end{array}$ & $\begin{array}{l}3,8 \% \\
(18)\end{array}$ \\
\hline $\begin{array}{l}\text { 33. I use literacy and numeracy strategies that } \\
\text { are appropriate with regards to cultural } \\
\text { diversity. }\end{array}$ & $\begin{array}{l}18,6 \% \\
(87)\end{array}$ & $\begin{array}{l}36,1 \% \\
(169)\end{array}$ & $\begin{array}{l}27,6 \% \\
(129)\end{array}$ & $\begin{array}{l}9 \% \\
(42)\end{array}$ & $\begin{array}{l}8,8 \% \\
(41)\end{array}$ \\
\hline \multirow{2}{*}{$\begin{array}{l}\text { 34. The respect of cultural diversity manifests } \\
\text { itself in my teaching of literacy and numeracy } \\
\text { by: } \\
\text { - taking into account the displays of } \\
\text { emotion of students from different } \\
\text { cultures; } \\
\text { - not treating students from different } \\
\text { cultures as a source of conflict. }\end{array}$} & $\begin{array}{l}20,5 \% \\
(96)\end{array}$ & $\begin{array}{l}38,2 \% \\
(179)\end{array}$ & $\begin{array}{l}16 \% \\
(75)\end{array}$ & $\begin{array}{l}4,1 \% \\
(19)\end{array}$ & $\begin{array}{l}21,2 \% \\
(99)\end{array}$ \\
\hline & $\begin{array}{l}39,5 \% \\
(185)\end{array}$ & $\begin{array}{l}28,8 \% \\
(135)\end{array}$ & $\begin{array}{l}5,6 \% \\
(26)\end{array}$ & $\begin{array}{l}3,8 \\
(18)\end{array}$ & $\begin{array}{l}22,2 \% \\
(104)\end{array}$ \\
\hline $\begin{array}{l}\text { 35. My literacy and numeracy practices include } \\
\text { follow-up activities that promote cultural } \\
\text { integration. }\end{array}$ & $\begin{array}{l}14,1 \% \\
(66)\end{array}$ & $\begin{array}{l}22,9 \% \\
(107)\end{array}$ & $\begin{array}{l}35,9 \% \\
(168)\end{array}$ & $\begin{array}{l}16 \% \\
(75)\end{array}$ & $\begin{array}{l}11,1 \% \\
(52)\end{array}$ \\
\hline $\begin{array}{l}\text { 36. My students are exposed to different points } \\
\text { of view and ways of thinking. }\end{array}$ & $\begin{array}{l}45,5 \% \\
(213)\end{array}$ & $\begin{array}{l}39,7 \% \\
(186)\end{array}$ & $\begin{array}{l}10,5 \% \\
(49)\end{array}$ & $\begin{array}{l}, 6 \% \\
(6)\end{array}$ & $\begin{array}{l}3,6 \% \\
(17)\end{array}$ \\
\hline $\begin{array}{l}\text { 37. I use group work as a way to encourage all } \\
\text { students to participate. }\end{array}$ & $\begin{array}{l}64,1 \% \\
(300)\end{array}$ & $\begin{array}{l}27,1 \% \\
(127)\end{array}$ & $\begin{array}{l}4,7 \% \\
(22)\end{array}$ & $\begin{array}{l}, 4 \% \\
(2)\end{array}$ & $\begin{array}{l}3,6 \% \\
(17)\end{array}$ \\
\hline $\begin{array}{l}\text { 38. I use group work as a way to form } \\
\text { homogeneous groups. }\end{array}$ & $\begin{array}{l}29,5 \% \\
(138)\end{array}$ & $\begin{array}{l}27,8 \% \\
(130)\end{array}$ & $\begin{array}{l}23,5 \% \\
(110)\end{array}$ & $\begin{array}{l}13,4 \% \\
(63)\end{array}$ & $\begin{array}{l}5,8 \% \\
(27)\end{array}$ \\
\hline $\begin{array}{l}\text { 39. I call on more timid students to encourage } \\
\text { them to participate in class. }\end{array}$ & $\begin{array}{l}40,6 \% \\
(190)\end{array}$ & $\begin{array}{l}34,2 \% \\
(160)\end{array}$ & $\begin{array}{l}18,4 \% \\
(86)\end{array}$ & $\begin{array}{l}2,6 \% \\
(12)\end{array}$ & $\begin{array}{l}4,3 \% \\
(20)\end{array}$ \\
\hline $\begin{array}{l}\text { 40. I allow students to work alone during } \\
\text { group work activities if they choose to do so. }\end{array}$ & $\begin{array}{l}17,9 \% \\
(84)\end{array}$ & $\begin{array}{l}23,1 \% \\
(108)\end{array}$ & $\begin{array}{l}39,7 \% \\
(186)\end{array}$ & $\begin{array}{l}15,6 \% \\
(73)\end{array}$ & $\begin{array}{l}3,6 \% \\
(17)\end{array}$ \\
\hline
\end{tabular}




\section{Table 6. Evaluation}

How often does the following happen in your classroom?

\begin{tabular}{|c|c|c|c|c|c|}
\hline & $\begin{array}{l}\text { Very } \\
\text { often }\end{array}$ & Often & Sometimes & Seldom & N/A \\
\hline $\begin{array}{l}\text { 41. I focus my teaching on elements } \\
\text { that make sense to my students. }\end{array}$ & $\begin{array}{l}58,5 \% \\
(274)\end{array}$ & $\begin{array}{l}33,5 \% \\
(157)\end{array}$ & $\begin{array}{l}4,3 \% \\
(20)\end{array}$ & & $\begin{array}{l}3,6 \% \\
(17)\end{array}$ \\
\hline $\begin{array}{l}\text { 42. My appreciation for literacy and } \\
\text { numeracy learning takes into account } \\
\text { the latest evaluation practices. }\end{array}$ & $\begin{array}{l}50,2 \% \\
(235)\end{array}$ & $\begin{array}{l}39,5 \% \\
(185)\end{array}$ & $\begin{array}{l}6,8 \% \\
(32)\end{array}$ & $\begin{array}{l}, 4 \% \\
(2)\end{array}$ & $\begin{array}{l}3 \% \\
(14)\end{array}$ \\
\hline $\begin{array}{l}\text { 43. Literacy and numeracy learning } \\
\text { evaluation is based on what is taught in } \\
\text { the classroom. }\end{array}$ & $\begin{array}{l}60,7 \% \\
(284)\end{array}$ & $\begin{array}{l}32,5 \% \\
(152)\end{array}$ & $\begin{array}{l}2,8 \% \\
(13)\end{array}$ & $\begin{array}{l}, 2 \% \\
(1)\end{array}$ & $\begin{array}{l}3,8 \% \\
(18)\end{array}$ \\
\hline $\begin{array}{l}\text { 44. I like to use evaluations tools } \\
\text { developed by others when they are } \\
\text { available (e.g. Ontario Ministry of } \\
\text { Education, TVO) }\end{array}$ & $\begin{array}{l}32,1 \% \\
(150)\end{array}$ & $\begin{array}{l}38,7 \% \\
(181)\end{array}$ & $\begin{array}{l}23,5 \% \\
(110)\end{array}$ & $\begin{array}{l}2,8 \% \\
(13)\end{array}$ & $\begin{array}{l}3 \% \\
(14)\end{array}$ \\
\hline $\begin{array}{l}\text { 45. I explain evaluation criteria to } \\
\text { students when evaluating them. }\end{array}$ & $\begin{array}{l}51,7 \% \\
(242)\end{array}$ & $\begin{array}{l}35,3 \% \\
(165)\end{array}$ & $\begin{array}{l}8,3 \% \\
(39)\end{array}$ & $\begin{array}{l}2,1 \% \\
(10)\end{array}$ & $\begin{array}{l}2,6 \% \\
(12)\end{array}$ \\
\hline $\begin{array}{l}\text { 46. I give students in my class the } \\
\text { opportunity to assess their work. }\end{array}$ & $\begin{array}{l}23,7 \% \\
(111)\end{array}$ & $\begin{array}{l}37,6 \% \\
(176)\end{array}$ & $\begin{array}{l}31 \% \\
(145)\end{array}$ & $\begin{array}{l}4,7 \% \\
(22)\end{array}$ & $\begin{array}{l}3 \% \\
(14)\end{array}$ \\
\hline $\begin{array}{l}\text { 47. The assessments I conduct help } \\
\text { primarily to identify my students' } \\
\text { shortcomings. }\end{array}$ & $\begin{array}{l}14,5 \% \\
(68)\end{array}$ & $\begin{array}{l}27,4 \% \\
(128)\end{array}$ & $\begin{array}{l}37,6 \% \\
(176)\end{array}$ & $\begin{array}{l}16,7 \% \\
(78)\end{array}$ & $\begin{array}{l}3,8 \% \\
(18)\end{array}$ \\
\hline $\begin{array}{l}\text { 48. Parents are aware of the } \\
\text { expectations that must be met in the } \\
\text { literacy and numeracy curricula. }\end{array}$ & $\begin{array}{l}33,5 \% \\
(157)\end{array}$ & $\begin{array}{l}42,5 \% \\
(199)\end{array}$ & $\begin{array}{l}16,2 \% \\
(76)\end{array}$ & $\begin{array}{l}3,2 \% \\
(15)\end{array}$ & $\begin{array}{l}4,5 \% \\
(21)\end{array}$ \\
\hline $\begin{array}{l}\text { 49. I take the time to evaluate my } \\
\text { students' knowledge of an element } \\
\text { before moving on to a new one. }\end{array}$ & $\begin{array}{l}38,9 \% \\
(182)\end{array}$ & $\begin{array}{l}45,9 \% \\
(215)\end{array}$ & $\begin{array}{l}10,7 \% \\
(50)\end{array}$ & $\begin{array}{l}1,1 \% \\
(5)\end{array}$ & $\begin{array}{l}3,4 \% \\
(16)\end{array}$ \\
\hline $\begin{array}{l}\text { 50. I participate in the decision-making } \\
\text { process concerning the way my } \\
\text { students' competencies are assessed. }\end{array}$ & $\begin{array}{l}42,1 \% \\
(197)\end{array}$ & $\begin{array}{l}40,8 \% \\
(191)\end{array}$ & $\begin{array}{l}10,5 \% \\
(49)\end{array}$ & $\begin{array}{l}1,7 \% \\
(8)\end{array}$ & $\begin{array}{l}4,9 \% \\
(23)\end{array}$ \\
\hline $\begin{array}{l}\text { 51. I feel as though I make professional } \\
\text { judgements when it comes to assessing } \\
\text { my students' general performance in } \\
\text { literacy and numeracy. }\end{array}$ & $\begin{array}{l}57,7 \% \\
(270)\end{array}$ & $\begin{array}{l}34 \% \\
(159)\end{array}$ & $\begin{array}{l}4,1 \% \\
(19)\end{array}$ & $\begin{array}{l}, 6 \% \\
(3)\end{array}$ & $\begin{array}{l}3,6 \% \\
(17)\end{array}$ \\
\hline $\begin{array}{l}\text { 52. In addition to achievement, I take } \\
\text { into account students' attitude when } \\
\text { assessing them. }\end{array}$ & $\begin{array}{l}32,3 \% \\
(151)\end{array}$ & $\begin{array}{l}34 \% \\
(159)\end{array}$ & $\begin{array}{l}20,9 \% \\
(98)\end{array}$ & $\begin{array}{l}9,8 \% \\
(46)\end{array}$ & $\begin{array}{l}3 \% \\
(14)\end{array}$ \\
\hline $\begin{array}{l}\text { 53. In addition to achievement, I take } \\
\text { into account the effort put forth by } \\
\text { students when assessing them. }\end{array}$ & $\begin{array}{l}39,5 \% \\
(185)\end{array}$ & $\begin{array}{l}37 \% \\
(173)\end{array}$ & $\begin{array}{l}17,3 \% \\
(81)\end{array}$ & $\begin{array}{l}3,2 \% \\
(15)\end{array}$ & $\begin{array}{l}3 \% \\
(14)\end{array}$ \\
\hline
\end{tabular}




\begin{tabular}{|c|c|c|c|c|c|}
\hline & $\begin{array}{l}\text { Very } \\
\text { often }\end{array}$ & Often & Sometimes & Seldom & N/A \\
\hline $\begin{array}{l}\text { 54. In addition to achievement, I take into } \\
\text { account students' motivation when assessing } \\
\text { them. }\end{array}$ & $\begin{array}{l}32,1 \% \\
(150)\end{array}$ & $\begin{array}{l}36,1 \% \\
(169)\end{array}$ & $\begin{array}{l}22,4 \% \\
(105)\end{array}$ & $\begin{array}{l}6,4 \% \\
(30)\end{array}$ & $\begin{array}{l}3 \% \\
(14)\end{array}$ \\
\hline $\begin{array}{l}\text { 55. In addition to achievement, I take into } \\
\text { account students' level of participation when } \\
\text { assessing them. }\end{array}$ & $\begin{array}{l}39,1 \% \\
(183)\end{array}$ & $\begin{array}{l}39,5 \% \\
(185)\end{array}$ & $\begin{array}{l}15,6 \% \\
(73)\end{array}$ & $\begin{array}{l}2,4 \% \\
(11)\end{array}$ & $\begin{array}{l}3,4 \% \\
(16)\end{array}$ \\
\hline $\begin{array}{l}\text { 56. I share with parents the various } \\
\text { evaluation criteria used for assessment. }\end{array}$ & $\begin{array}{l}39,5 \% \\
(185)\end{array}$ & $\begin{array}{l}40 \% \\
(187)\end{array}$ & $\begin{array}{l}14,3 \% \\
(67)\end{array}$ & $\begin{array}{l}3,2 \% \\
(15)\end{array}$ & $\begin{array}{l}3 \% \\
(14)\end{array}$ \\
\hline $\begin{array}{l}\text { 57. The assessment I conduct helps to } \\
\text { determine my students' strong points. }\end{array}$ & $\begin{array}{l}51,5 \% \\
(241)\end{array}$ & $\begin{array}{l}42,1 \% \\
(197)\end{array}$ & $\begin{array}{l}3,6 \% \\
(17)\end{array}$ & $\begin{array}{l}, 2 \% \\
(1)\end{array}$ & $\begin{array}{l}2,6 \% \\
(12)\end{array}$ \\
\hline
\end{tabular}


Figure 1. Number of Years Teaching at the Elementary Level

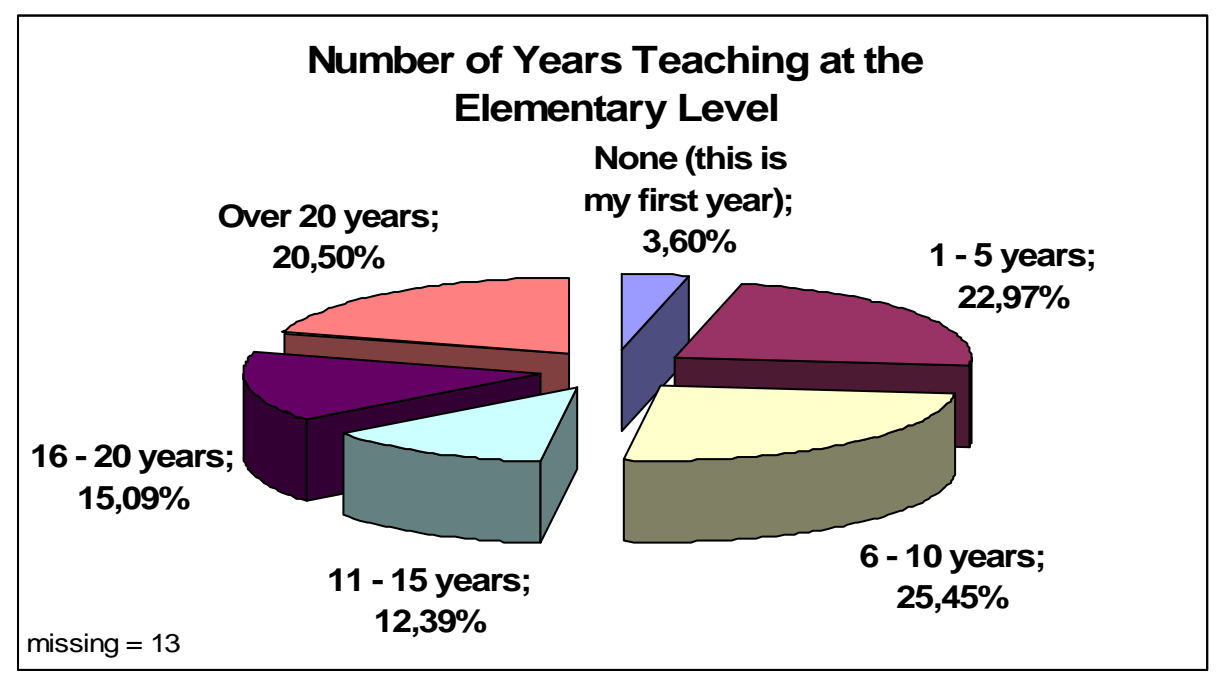

Figure 2. Level Taught in the Past for at Least a Full Year

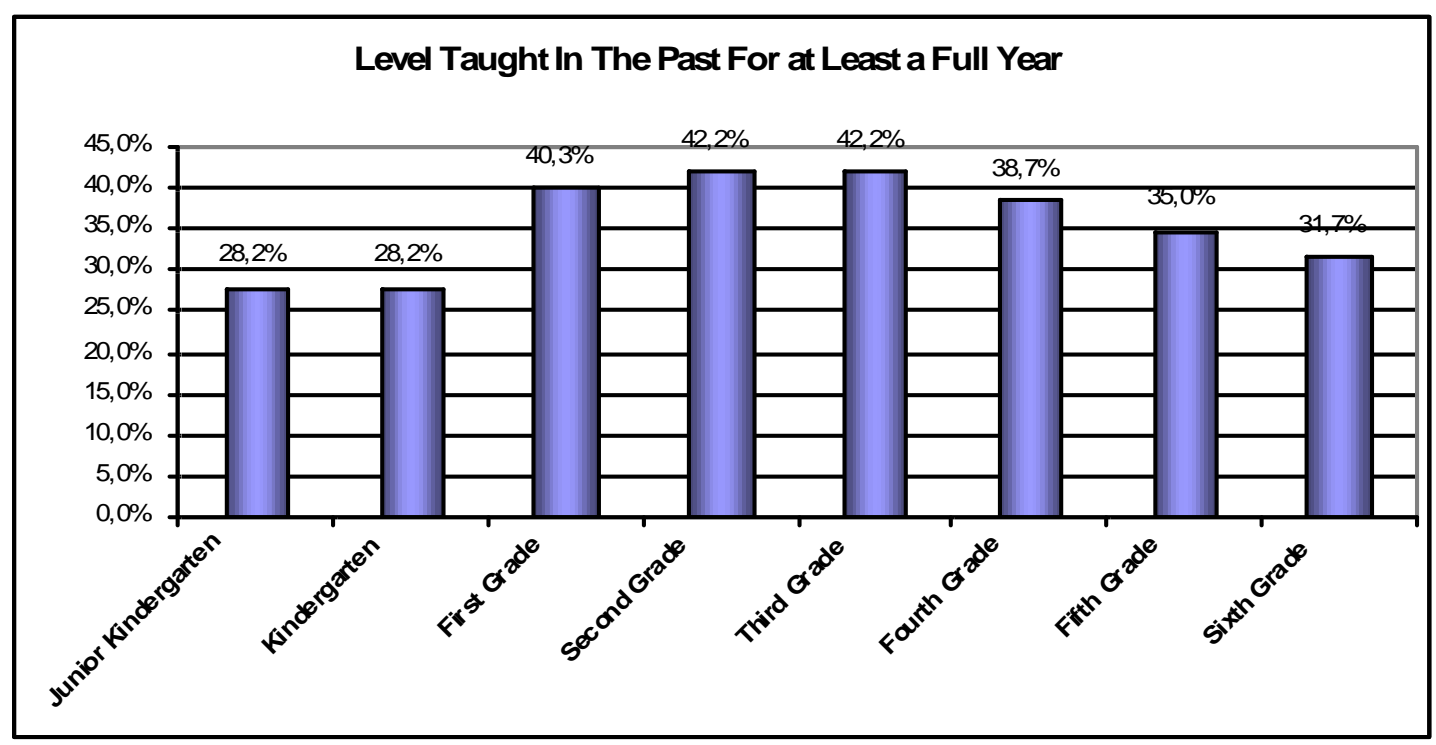


Figure 3. School Description (Total Population)

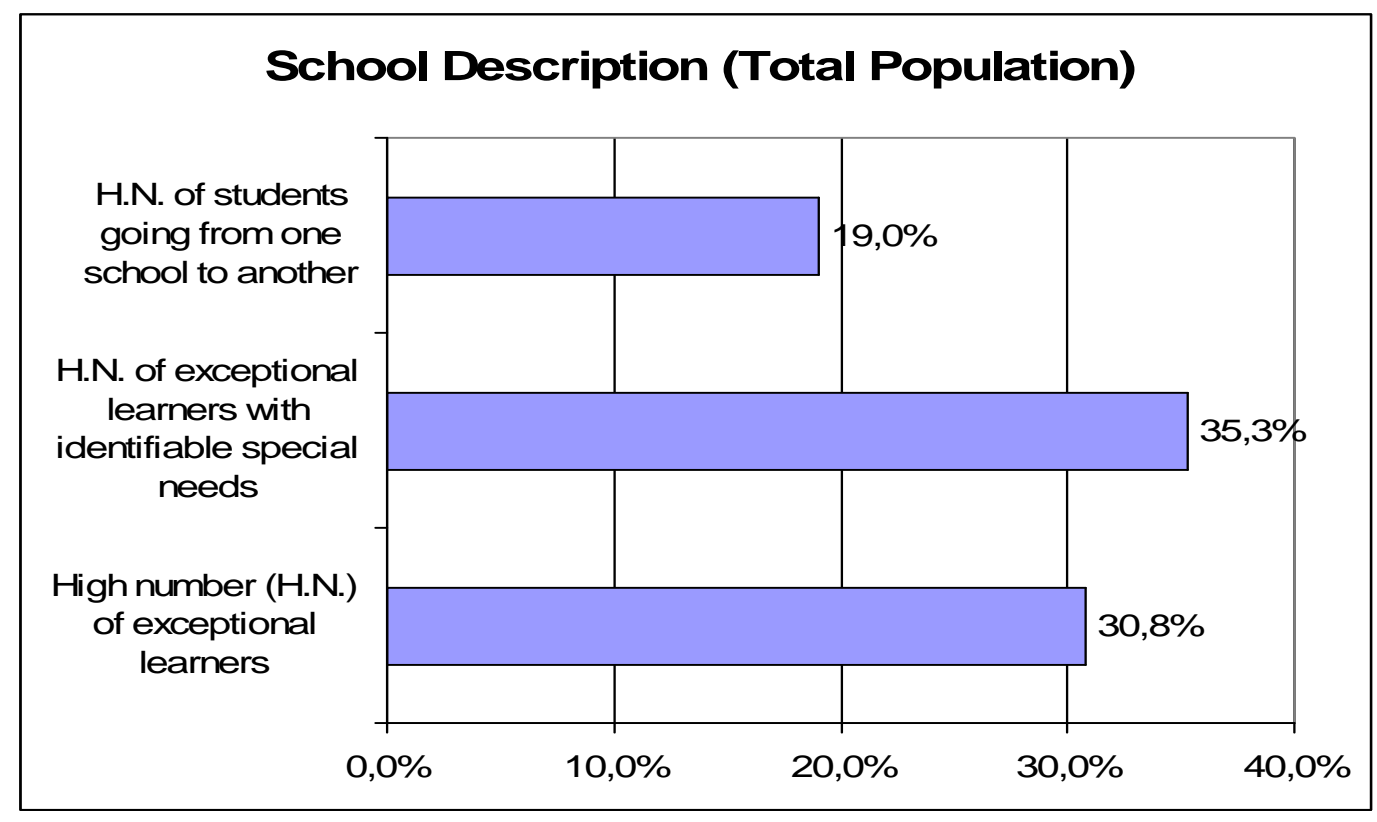

Figure 4. School Description (Francophone Population)

\section{School Description (Francophone Population)}

H.N. of Francophone student of a foreign nationality

H.N. of students in a PDF Program

H.N. of students in an ALF Program

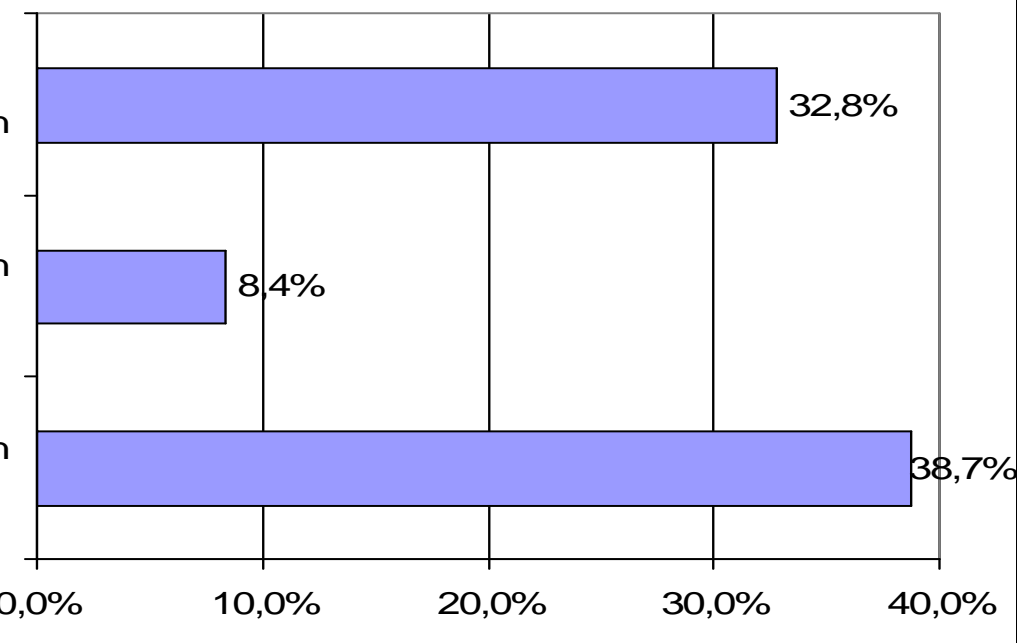


Figure 5. Training Background in Literacy and Numeracy

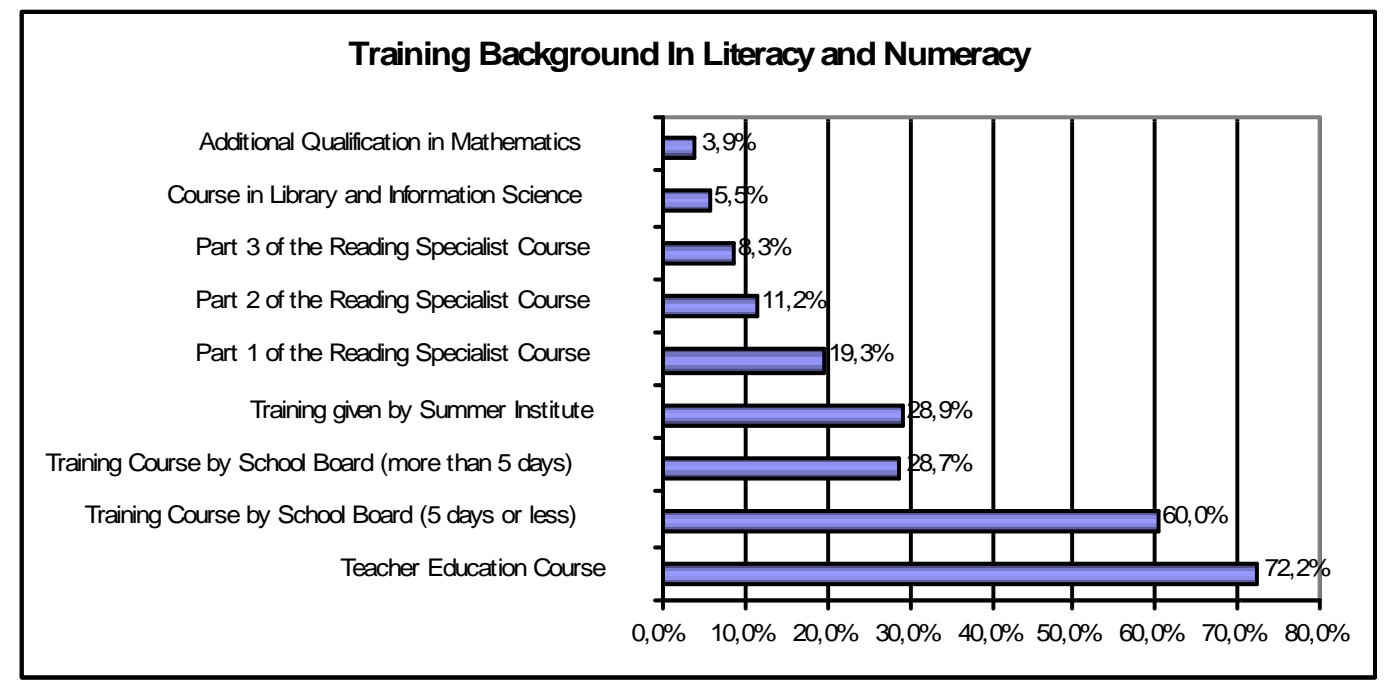

